\title{
PENGARUH PEMBIAYAAN ULTRA MIKRO (UMI) TERHADAP PERTUMBUHAN EKONOMI DAERAH MELALUI PERTUMBUHAN PRODUKSI INDUSTRI MIKRO DAN KECIL
}

\author{
Vincencia Dian Priliyanti Hia \\ Direktorat Jenderal Perbendaharaan \\ Riya Dwi Handaka \\ PKN STAN \\ Yuris Trisman Zega \\ Badan Pusat Statistik \\ Alamat Korespondensi: vincencia.d@kemenkeu.go.id
}

\begin{abstract}
To maintain and increase economic growth rates above 5 percent, since 2017, Indonesia has launched an Ultra Micro Financing program for enterprises below micro and small categories (ultra micro enterprises). The financing is used to complement other types of financing, which is a bank loan for micro, small, and medium enterprises. Using regression method and causal testing to a panel data of 33 provinces in Indonesia during 2017 till 2018, this study aims to prove the direct and indirect effect of MSEs financing on regional economic growth and production growth in provincial regions in Indonesia. This research shows that the MSEs financing has positive impact on the manufacturing production growth but no significant impact on regional economic growth that is shown by Gross Domestic Product (GDP). This research also proves that manufacturing production has significant impact on GDP.
\end{abstract}

\begin{abstract}
ABSTRAK
Dalam usaha mencapai tingkat ekonomi di atas 5 persen, sejak tahun 2017, pemerintah Indonesia telah menerbitkan Pembiayaan Ultra Mikro (UMi), suatu program pembiayaan yang menyasar usaha di bawah kategori mikro dan kecil, yaitu usaha ultra mikro. Pembiayaan ini merupakan program komplementer atas Kredit Usaha Rakyat (KUR), yang berbentuk pinjaman bank terhadap usaha mikro, kecil dan menengah (UMKM). Dengan metode regresi dan analisis jalur atas data panel dari 33 provinsi di Indonesia tahun 2017-2018, penelitian ini bertujuan untuk melihat ada tidaknya pengaruh Pembiayaan Ultra Mikro terhadap pertumbuhan ekonomi regional dan pertumbuhan produksi industri mikro dan kecil di tingkat provinsi. Penelitian ini membuktikan bahwa Pembiayaan Ultra Mikro berpengaruh signifikan terhadap pertumbuhan produksi industri mikro dan kecil namun tidak signifikan terhadap pertumbuhan ekonomi regional, yang ditunjukkan oleh PDRB.
\end{abstract}

KATA KUNCI:

Pembiayaan, UMi, UMKM, PDRB, Produksi.

Financing, Micro and Small Enterprises, Production, Economic Growth.

\section{KLASIFIKASI JEL:}

043, D24, G32

\section{CARA MENGUTIP:}

Hia, V.D.P, Handaka R.D, \& Zega Y.T. (2021). Pengaruh pembiayaan ultra mikro (umi) terhadap pertumbuhan ekonomi daerah melalui pertumbuhan produksi industri mikro dan kecil. Indonesian Treasury Review: Jurnal Perbendaharaan, Keuangan Negara dan Kebijakan Publik, 6(1), 75-84. 


\section{PENDAHULUAN}

Usaha mikro, kecil dan menengah (UMKM) memainkan peran penting pada perekenomian dunia, khususnya di Asia (Ooi, Atkinson, \& Messy, 2017). Asian Development Bank (ADB) mencatat bahwa pada tahun 2015, 96 persen dari total jenis usaha di Asia adalah UMKM, yang mempekerjakan 62 persen dari total tenaga kerja, dengan kontribusi rata-rata terhadap Produk Domestik Bruto (PDB) adalah sebesar 42 persen.

Data sensus ekonomi tahun 2016 yang dirilis oleh Badan Pusat Statistik (BPS) menunjukkan bahwa Indonesia memiliki 26,71 juta usaha, yang didominasi UMKM. Bila diklasifikasikan berdasarkan skala usaha, 26,26 juta usaha $(98,33$ persen) diantaranya tergolong usaha mikro kecil dan 0,45 juta usaha (1,67 persen) tergolong usaha menengah dan besar. Usaha mikro kecil juga mampu menyerap 59,26 juta tenaga kerja atau 75 persen tenaga kerja di Indonesia. Meskipun pertumbuhan ekonomi cenderung stagnan sejak 2011, sektor UMKM mampu menopang perekonomian nasional dengan kontribusi terbesar terhadap PDB, sebesar 60,3 persen (Wardhono, Modjo, \& Utami, 2019).

Permasalahan utama yang dialami oleh UMKM khususnya usaha mikro dan kecil adalah keterbatasan akses untuk mendapatkan modal memulai dan mengembangkan usaha. UMKM memiliki kesulitan memperoleh sumber daya keuangan yang memadai untuk membeli mesin atau peralatan dan bahan baku untuk produksi (Panigrahi, 2012). Pemerintah Indonesia telah menyediakan dukungan pendanaan bagi UMKM melalui kredit program, baik dengan skema subsidi bunga maupun skema dana bergulir. Kredit Usaha Rakyat (KUR) merupakan salah satu kredit program pemerintah yang menggunakan skema subsidi bunga dan telah diluncurkan sejak Agustus 2015. Meskipun begitu, berdasarkan data dari Pusat Investasi Pemerintah, pada tahun 2017, terdapat 44.582.840 unit UMKM atau 70,73 persen dari total UMKM di Indonesia yang belum memperoleh KUR. Rendahnya persentase jangkauan KUR terhadap UMKM dikarenakan umumnya usaha mikro tidak cukup bankable untuk mendapatkan layanan perbankan.

Menyikapi hal tersebut, pada tahun 2017, pemerintah Indonesia meluncurkan sebuah kredit program dengan skema dana bergulir yang menyasar pelaku usaha ultra mikro (UMi). Pembiayaan Ultra Mikro (UMi) adalah program komplementer Kredit Usaha Rakyat (KUR) yang menyasar pelaku usaha yang tidak memiliki akses terhadap layanan perbankan. Sejak diluncurkan pada tahun 2017 hingga tahun 2019, pemerintah telah mengalokasikan dana sebesar Rp7 T untuk pembiayaan UMi. Pada tahun 2017, anggaran sebesar Rp1,5 T telah direalisasikan sebanyak 50 persen dan disalurkan kepada 307.000 debitur. Kemudian pada tahun 2018, pemerintah kembali mengalokasikan Rp2,5 T untuk Pembiayaan UMi dan berhasil menyalurkan lebih dari Rp1 T kepada 846.547 debitur. Dampak dari program KUR dan Pembiayaan UMi diharapkan mampu menggerakkan pertumbuhan ekonomi yang pada akhirnya meningkatkan pendapatan perkapita dan daya beli masyarakat.

Salah satu sektor yang menjadi prioritas program KUR dan Pembiayaan UMi adalah sektor industri pengolahan. Menteri Perindustrian Airlangga Hartarto (2017) mengatakan bahwa target realisasi KUR yang ideal untuk industri kecil dan menengah adalah sebesar 30 persen. Angka tersebut dinilai ideal untuk mendorong produksi dan menciptakan kewirausahaan baru. Keseriusan ini didorong oleh perekonomian Indonesia yang didominasi sektor industri pengolahan. BPS mencatat sejak tahun 2014-2018 kontribusi industri pengolahan terhadap Produk Domestik Bruto (PDB) rata-rata mencapai 20,52 persen, terbesar diantara sektor lainnya bahkan di dalam RPJMN tahun 2015-2019, proyeksi kontribusi tertinggi terhadap PDB juga berasal dari sektor industri pengolahan yaitu mencapai 21,2 persen.

Tabel 1. Kontribusi Masing-Masing Lapangan

Usaha terhadap PDB Tahun 2014 s.d. 2018

\begin{tabular}{|l|r|r|r|r|r|}
\hline \multicolumn{1}{|l|}{ PDB Lapangan Usaha } & $\mathbf{2 0 1 8}$ & $\mathbf{2 0 1 7}$ & $\mathbf{2 0 1 6}$ & $\mathbf{2 0 1 5}$ & $\mathbf{2 0 1 4}$ \\
\hline $\begin{array}{l}\text { A. Pertanian, Kehutanan, dan } \\
\text { Perikanan }\end{array}$ & 12,81 & 13,16 & 13,48 & 13,49 & 13,34 \\
\hline $\begin{array}{l}\text { B. Pertambangan dan } \\
\text { Penggalian }\end{array}$ & 8,08 & 7,58 & 7,18 & 7,65 & 9,83 \\
\hline C. Industri Pengolahan & 19,86 & 20,16 & 20,52 & 20,99 & 21,08 \\
\hline D. Pengadaan Listrik dan Gas & 1,19 & 1,19 & 1,15 & 1,13 & 1,09 \\
\hline $\begin{array}{l}\text { E. Pengadaan Air, Pengelolaan } \\
\text { Sampah, Limbah dan Daur } \\
\text { Ulang }\end{array}$ & 0,07 & 0,07 & 0,07 & 0,07 & 0,07 \\
\hline F. Konstruksi & 10,53 & 10,38 & 10,38 & 10,21 & 9,86 \\
\hline $\begin{array}{l}\text { G. Perdagangan Besar dan } \\
\text { Eceran; Reparasi Mobil dan } \\
\text { Sepeda Motor }\end{array}$ & 13,02 & 13,02 & 13,19 & 13,30 & 13,43 \\
\hline $\begin{array}{l}\text { H. Transportasi dan } \\
\text { Pergudangan }\end{array}$ & 5,38 & 5,41 & 5,20 & 5,02 & 4,42 \\
\hline $\begin{array}{l}\text { I. Penyediaan Akomodasi dan } \\
\text { Makan Minum }\end{array}$ & 2,78 & 2,85 & 2,93 & 2,96 & 3,04 \\
\hline J. Informasi dan Komunikasi & 3,77 & 3,78 & 3,62 & 3,52 & 3,50 \\
\hline K. Jasa Keuangan dan Asuransi & 4,15 & 4,20 & 4,19 & 4,03 & 3,86 \\
\hline L. Real Estate & 2,74 & 2,81 & 2,83 & 2,84 & 2,79 \\
\hline M,N. Jasa Perusahaan & 1,80 & 1,75 & 1,71 & 1,65 & 1,57 \\
\hline $\begin{array}{l}\text { O. Adm Pemerintahan, } \\
\text { Pertahanan, dan Jaminan } \\
\text { Sosial Wajib }\end{array}$ & 3,65 & 3,67 & 3,84 & 3,90 & 3,83 \\
\hline P. Jasa Pendidikan & 3,25 & 3,29 & 3,27 & 3,26 & 3,23 \\
\hline $\begin{array}{l}\text { Q. Jasa Kesehatan jan Kegiatan } \\
\text { Sosial }\end{array}$ & 1,07 & 1,07 & 1,07 & 1,07 & 1,03 \\
\hline R,S,T,U. Jasa Lainnya & 1,81 & 1,76 & 1,70 & 1,65 & 1,55 \\
\hline Sumber: Badan PuSat Statis & & & \\
\hline
\end{tabular}

Sumber: Badan Pusat Statistik. bps.go.id

Berdasarkan Tabel 1 diketahui bahwa meskipun memberi kontribusi tertinggi terhadap PDB tahun 2014 s.d. 2018, namun persentase kontribusinya cenderung menurun. Hal ini berbanding terbalik dengan semakin bertambahnya realisasi Pembiayaan UMi yang telah disalurkan pemerintah.

Dominasi jumlah UMKM terhadap perekonomian Indonesia, semakin bertambahnya 
jumlah realisasi Pembiayaan UMi namun stagnannya kontribusi industri pengolahan terhadap PDRB menjadi latar belakang dilakukannya penelitian ini. Tujuan dari penelitian ini adalah untuk menganalisis dampak Pembiayaan UMi terhadap pertumbuhan produksi industri mikro kecil dan pertumbuhan ekonomi daerah (PDRB). Berdasarkan latar belakang dan tujuan tersebut, peneliti kemudian merumuskan hipotesis penelitian sebagai berikut.

$\mathrm{H}_{1}$ : Pembiayaan UMi berpengaruh signifikan terhadap PDRB sektor industri pengolahan.

$\mathrm{H}_{2}$ : Pembiayaan UMi berpengaruh signifikan terhadap pertumbuhan produksi industri mikro dan kecil.

$\mathrm{H}_{3}$ : Pembiayaan produksi industri mikro dan kecil berpengaruh signifikan terhadap pertumbuhan ekonomi daerah (PDRB).

$\mathrm{H}_{4}$ : Pembiayaan UMi berpengaruh signifikan terhadap pertumbuhan ekonomi daerah (PDRB) melalui pertumbuhan produksi industri mikro dan kecil.

\section{LANDASAN TEORI}

\subsection{Usaha Mikro dan Kecil}

Usaha mikro didefinisikan sebagai usaha yang memiliki kekayaan bersih maksimal sebesar Rp50.000.000,00 tidak termasuk tanah dan bangunan tempat usaha, atau memiliki omzet tahunan maksimal sebesar Rp300.000.000,00, sedangkan usaha kecil adalah usaha dengan kekayaan bersih sebesar Rp50.000.000,00 hingga Rp500.000.000,00 selain tanah dan bangunan tempat usaha atau memiliki omzet tahunan sebesar Rp300.000.000,00 hingga Rp2.500.000.000,00 (Indonesia, 2008). Pembiayaan Ultra Mikro (UMi) menyasar UMKM yang tidak cukup bankable atau memiliki kapasitas di bawah usaha mikro.

UMKM bergerak dalam berbagai sektor di antaranya sektor perdagangan, sektor pertanian, peternakan, perkebunan, dan sektor industri pengolahan. Objek penelitian ini merupakan industri pengolahan dengan kategori usaha mikro dan kecil. Objek penelitian ini dipilih untuk dapat melihat dampak Pembiayaan UMi terhadap perekonomian rakyat. Dalam publikasi Profil Industri Mikro dan Kecil, Badan Pusat Statistik (BPS) mengklasifikasikan industri mikro sebagai industri pengolahan yang mempekerjakan 1-4 orang tenaga kerja sedangkan industri kecil adalah industri pengolahan yang mempekerjakan 5-19 orang tenaga kerja.

\subsection{Pembiayaan}

Dalam rangka membantu penyelesaian permasalahan UMKM yang dialami negara-negara di dunia, ILO menyarankan agar pemerintah memusatkan perhatiannya pada masalah kredit dan melakukan pendekatan proaktif terhadap pelaku usaha, seperti yang telah dipraktikkan di beberapa negara lain (Vandenberg, 2009). Pemerintah menyalurkan berbagai program pembiayaan sebagai bentuk investasi pemerintah kepada usaha mikro dan kecil dengan tujuan meningkatkan perekonomian pelaku usaha sekaligus memajukan kesejahteraan umum.

Ditinjau dari definisi, investasi adalah keputusan untuk melepaskan dana saat ini dengan harapan memperoleh aliran dana masuk dengan jumlah dana yang lebih besar dibandingkan jumlah dana yang dilepaskan (Mulyadi, 2006, 121). Sumber lain menyatakan bahwa investasi adalah komitmen saat ini atas sejumlah dana atau sumber daya lainnya dengan tujuan memperoleh keuntungan di masa depan (Tandelilin, 2010, 2).

Menurut Peraturan Pemerintah Nomor 63 Tahun 2019 tentang Investasi Pemerintah, investasi pemerintah adalah penempatan sejumlah dan/atau barang dalam jangka panjang untuk investasi pembelian surat berharga dan investasi langsung untuk memperoleh manfaat ekonomi, sosial, dan/atau manfaat lainnya. Lebih lanjut lagi dijelaskan bahwa investasi langsung adalah penyertaan modal dan/atau pemberian pinjaman oleh badan investasi pemerintah untuk membiayai kegiatan usaha. Pemberian pinjaman adalah bentuk investasi pemerintah pada badan usaha, badan layanan umum (BLU), pemerintah daerah, dan badan layanan umum daerah (BLUD) dengan hak memperoleh pengembalian berupa pokok pinjaman, bunga, dan/atau biaya lainnya. Dalam praktiknya, pemberian pinjaman dikenal juga dengan istilah pembiayaan

Pembiayaan adalah fasilitas penyediaan dana untuk pihak-pihak yang mengalami defisit unit (Antonio, 2001, 160). Selain itu, menurut Rivai dan Arifin (2010, 681), pembiayaan adalah transfer pendanaan antar pihak untuk merealisasikan rencana investasi, baik yang dilaksanakan sendiri dan/atau lembaga. Berdasarkan laporan Direktorat Jenderal Perbendaharaan yang dituliskan pada Majalah Treasury Indonesia Nomor 1 Tahun 2018, tantangan terbesar usaha mikro dan kecil di Indonesia adalah keterbatasan modal usaha. Oleh sebab itu, pemerintah memberikan bantuan modal dalam bentuk pinjaman atau pembiayaan dengan hak atas pokok pinjaman, bunga dan atau biaya lain. Pembiayaan Ultra Mikro (UMi) merupakan fasilitas pemberian pinjaman dalam bentuk kredit konvensional maupun Syariah yang menyasar pengusaha ultra mikro (Menteri Keuangan, 2018). Program ini bertujuan untuk mempermudah dan mempercepat proses perolehan pinjaman modal bagi pelaku usaha ultra mikro sekaligus memperlebar peluang usaha. Pembiayaan ini diharapkan dapat mengatasi alasan utama terhambatnya pertumbuhan UMKM yaitu 
pembiayaan yang tidak memadai oleh bank dan persyaratan agunan yang tinggi (Gupta et al., 2018).

\subsection{Pembiayaan Ultra Mikro (UMi)}

Berdasarkan Peraturan Menteri Keuangan Nomor 95/PMK.05/2018 tentang Pembiayaan Ultra Mikro, pemerintah menetapkan Badan Layanan Umum Pusat Investasi Pemerintah (BLU PIP) sebagai koordinator Pembiayaan UMi yang bertugas menghimpun dan menyalurkan dana. Pembiayaan UMi disalurkan oleh Pusat Investasi Pemerintah (PIP) melalui Lembaga Keuangan Bukan Bank (LKBB) yang terdiri atas PT. Pegadaian Persero, PT. Permodalan Nasional Madani (PNM), dan PT. Bahana Artha Ventura (BAV). Masingmasing penyalur tersebut memiliki berbagai skema penyaluran yang diterapkan tanpa mensyaratkan jaminan, memberi akses kepada pengusaha ultra mikro untuk mendapatkan pinjaman, mendampingi dan menguatkan debitur untuk menekan non performing loan (NPL).

Risiko non performing loan (NPL) ditekan tidak semata-mata dengan menggunakan jaminan, namun dengan pendekatan persuasif, tanggung renteng dalam kelompok ibu maupun angsuran. LKBB tersebut kemudian menyalurkan dana kepada para pelaku usaha melalui koperasi sehingga cakupan wilayah Pembiayaan UMi ini lebih luas dan lebih dekat kepada masyarakat. Skema ini sesuai dengan hasil penelitian yang menyimpulkan bahwa jangkauan layanan keuangan kepada masyarakat berpengaruh positif dan signifikan pada upaya pengentasan kemiskinan (Rewilak, 2017).

\subsection{Produk Domestik Regional Bruto (PDRB)}

Beberapa penelitian sebelumnya mengaitkan peranan UMKM dengan pertumbuhan ekonomi suatu negara. Salah satu indikator pertumbuhan ekonomi suatu negara adalah Produk Domestik Regional Bruto (PDRB), dengan UMKM sebagai penyokongnya. Haller (2012) menyebutkan bahwa pertumbuhan ekonomi memberi efek positif pada kehidupan sosial dan ekonomi, seperti pembangunan dan peningkatan standar kehidupan. Indonesia merupakan negara kepulauan dan terbagi dalam beberapa wilayah, untuk itu Produk Domestik Regional Bruto (PDRB) digunakan sebagai indikator prestasi pembangunan perekonomian suatu wilayah yang disesuaikan dengan potensi regional.

Salah satu cara perhitungan PDRB adalah dengan pendekatan produksi, dimana produksi didefinisikan sebagai kegiatan ekonomi yang mengolah suatu barang menjadi barang setengah jadi atau barang jadi dan memiliki nilai yang lebih tinggi. Fungsi produksi Cobb-Douglas menyatakan bahwa kuantitas produksi dapat ditentukan oleh 3 faktor yaitu kapital atau modal, tenaga kerja dan produktifitas (Cobb \& Douglas, 1928). Oleh sebab itu, kekayaan nasional juga ditentukan oleh kapasitas produksi.

\subsection{Studi Terdahulu}

Beberapa peneliti terdahulu telah membuktikan adanya hubungan modal dengan produksi. Dalam penelitian yang dilakukan oleh Batool dan Zulfiqar (2013) pada usaha mikro kecil di Pakistan, disimpulkan bahwa modal dan tenaga kerja memberi pengaruh signifikan dan positif terhadap produksi. Penelitian lain pada usaha kecil menengah di Tanzania, menyatakan bahwa keterampilan/skill dan modal berpengaruh signifikan terhadap produktivitas UKM (Assefa Admassie \& Matambalya, 2002). Dalam penelitian di Indonesia pada usaha kecil menengah di UIN Jakarta didapatkan hasil bahwa modal, tenaga kerja dan teknologi berpengaruh positif dan siginifikan terhadap produksi. Tenaga kerja memiliki signifikansi tertinggi sedangkan tingkat pendidikan tidak berpengaruh signifikan (Amalia, 2014). Penelitian-penelitian terdahulu tersebut menjadi dasar bagi peneliti untuk menggunakan jumlah industri mikro dan kecil (IMK) dan pendidikan (Pd) sebagai variabel kontrol.

Rewilak (2017) menyimpulkan bahwa memperluas dan memperdalam jangkauan layanan keuangan kepada masyarakat memiliki pengaruh positif dan signifikansi tertinggi pada upaya pengentasan kemiskinan. Meningkatkan kemudahan akses fisik terhadap layanan keuangan seperti menambah cabang bank di berbagai pelosok daerah juga berpengaruh positif terhadap pengentasan kemiskinan. Rewilak juga menyatakan bahwa pengeluaran pemerintah memiliki pengaruh positif signifikan terhadap jumlah masyarakat miskin. Hal inilah yang menjadi dasar bagi peneliti untuk menggunakan Pembentukan Modal Tetap Bruto (PMTB) sebagai variabel kontrol karena PMTB merupakan pengeluaran pemerintah untuk infrastruktur dan merupakan salah satu komponen Produk Domestik Regional Bruto (PDRB). Infrastruktur yang baik memudahkan proses suplai bahan baku, pengolahan dan distribusi produk.

Sebelum Pembiayaan UMi diluncurkan oleh pemerintah, KUR merupakan salah satu alternatif perolehan modal bagi UMKM. Jannah dan Wibowo (2017) menyimpulkan bahwa KUR, omset, jumlah tenaga kerja, dan jumlah UMKM berpengaruh signifikan terhadap industri pengolahan di Jawa Tengah. Hal ini sejalan dengan penelitian Iztihar (2018) yang menyatakan bahwa KUR berpengaruh positif dan signifikan terhadap jumlah UMKM, tenaga kerja, nilai output, dan PDRB. Variabel KUR sebagai modal yang digunakan dalam penelitianpenelitian tersebut menjadi dasar bagi peneliti untuk menggunakan Pembiayaan UMi sebagai variabel independen dan output produksi industri mikro dan kecil (OUTPUT_PROD) sebagai variabel mediasi. 


\section{METODOLOGI PENELITIAN}

Penelitian ini adalah penelitian kuantitatif yang menggunakan data sekunder dari Badan Pusat Statistik (BPS), Kementerian Keuangan, Pusat Investasi Pemerintah, dan sumber lainnya. Penelitian ini menggunakan data penyaluran Pembiayaan UMi di 33 provinsi di Indonesia selama dua tahun pada tahun 2017-2018. Data yang digunakan hanya berasal dari 33 provinsi di Indonesia karena pada tahun 2017-2018, Provinsi Kalimantan Utara belum menerima Pembiayaan UMi. Periode ini dipilih karena Pembiayaan UMi diluncurkan pertama kali pada tahun 2017.

Variabel pada penelitian ini terdiri dari pertumbuhan ekonomi daerah yang diwakili oleh PDRB sektor industri pengolahan sebagai variabel dependen, Pembiayaan UMi sebagai variabel independen, dan pertumbuhan produksi industri mikro dan kecil (OUTPUT_PROD) sebagai variabel mediasi. Selain itu, pada model penelitian ini juga mengikutsertakan variabel kontrol berupa Pembentukan Modal Tetap Bruto (PMTB) yang menunjukkan pengeluaran suatu provinsi untuk barang modal dan bukan untuk dikonsumsi, jumlah industri mikro dan kecil (IMK), serta Pendidikan (Pd) yang menunjukkan rata-rata lama sekolah masyarakat yang berusia di atas 25 tahun pada masing-masing provinsi.

Sesuai dengan teori produksi Cobb-Douglas, pada penelitian ini, Pembiayaan UMi sebagai faktor kapital atau modal; PMTB, jumlah industri mikro dan kecil (IMK), dan tingkat pendidikan (Pd) sebagai unsur tenaga kerja dan produktivitas. Adapun model penelitian ini digambarkan melalui persamaan berikut.

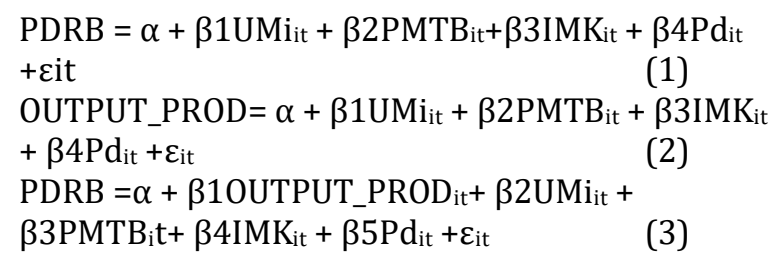

Keterangan:

OUTPUT_PROD = Output produksi industri

pengolahan skala mikro dan kecil

PDRB = Produk Domestik Regional Bruto

Sektor Industri Pengolahan

UMi = Pembiayaan Ultra Mikro

PMTB = Pembentukan Modal Tetap Bruto

IMK = Jumlah Industri Mikro dan Kecil

$\mathrm{Pd} \quad=$ Rata-rata Lama Sekolah

$\alpha \quad=$ Konstanta

$\beta_{1}$ s.d. $\beta_{5}=$ Koefisien Regresi

$\varepsilon \quad=$ error term

Hubungan persamaan dengan tujuan penelitian yang dibentuk dalam sebuah hipotesis dapat digambarkan pada gambar 1 .

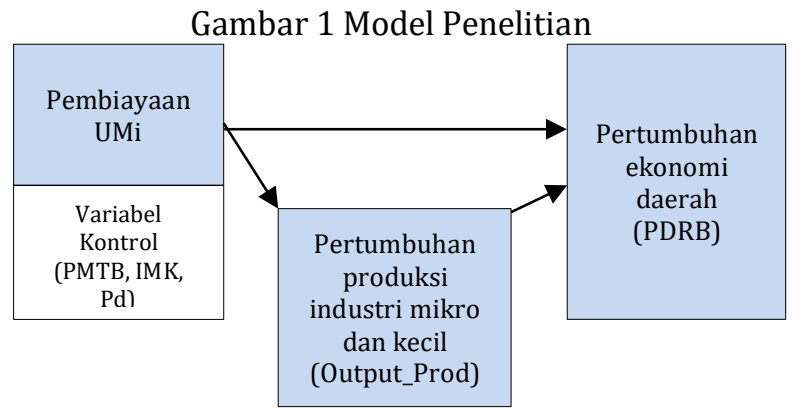

Sumber: Diolah oleh Penulis

Regresi data panel digunakan untuk menganalisis data dengan hipotesis yang dibentuk. Model yang digunakan setelah melalui serangkaian tes baik uji Chow, uji Hausman, dan uji LM adalah Fixed Effect Method. Namun karena data penelitian ini hanya memiliki rentan waktu penelitian selama dua tahun dan untuk menghindari hasil bias (spurious regression) yang diakibatkan nilai Rsquared model yang mendekati angka 1 (hampir sempurna) maka peneliti memutuskan untuk menggunakan Random Effect Method. Hal ini didukung oleh pernyataan Gujarati (2003, 651) Gujarati $(2003,651)$ yang menyatakan bahwa jika jumlah individu lebih besar daripada jumlah waktu $(n>t)$, maka RE lebih efisien dibandingkan FE. Pendapat lain mengatakan bahwa FE dan RE samasama dapat melakukan estimasi dengan baik namun RE mampu mengestimasi dengan lebih tepat. Hal ini disebabkan standard error pada RE lebih kecil sehingga hasil estimasi RE akan lebih representatif (Hofmann \& Werkheiser, 2017). Uji asumsi klasik menunjukkan bahwa variabel-variabel yang digunakan telah terbebas dari heteroskedasitas dan autokorelasi. Adapun untuk mengatasi masalah multikolinearitas, peneliti melakukan transformasi berupa logaritma natural terhadap beberapa variabel independen yaitu LOG(PDRB), LOG(OUTPUT_PROD), LOG(UMI), PMTB, IMK, dan PD.

Selain melakukan regresi data panel, dilakukan juga pembuktian analisis jalur untuk menguji ada tidaknya hubungan tidak langsung antara variabel dependen pertumbuhan ekonomi daerah (PDRB) dengan variabel independen Pembiayaan Ultra Mikro (UMi) melalui pertumbuhan produksi industri mikro dan kecil sebagai variabel mediasi dalam model penelitian ini.

\section{HASIL PENELITIAN}

Sejak pertama kali diluncurkan pada tahun 2017 hingga 30 November 2019, Pusat Investasi Pemerintah telah menyalurkan Pembiayaan UMi sebesar lebih dari 3,9 triliun rupiah kepada 1.368.911 debitur. Penyaluran Pembiayaan UMi didominasi oleh sektor usaha perdagangan yaitu sebesar 91,92 persen dari total dana yang disalurkan, sedangkan sisanya untuk sektor 
pertanian, peternakan, perkebunan, perikanan, dan industri pengolahan.

Berdasarkan Tabel 2, rata-rata realisasi Pembiayaan UMi pada tahun 2017-2018 adalah Rp35,113 M. Nilai minimum Pembiayaan UMi sebesar 0,0326 menunjukkan realisasi Pembiayaan UMi pada tahun 2017-2018 adalah sebesar Rp0,0326 M atau Rp32,6 juta. Angka ini diperoleh Provinsi Maluku Utara tahun 2017. Nilai maksimum Pembiayaan UMi adalah sebesar 417,616 yang menunjukkan realisasi Pembiayaan UMi tertinggi dalam periode 2017-2018 diperoleh Provinsi Jawa Tengah sebesar Rp417,616 M pada tahun 2018. Adapun rata-rata PDRB sektor industri pengolahan seluruh provinsi di Indonesia selama tahun 20172018 adalah sebesar Rp74.048,73 M. PDRB tertinggi dicapai oleh Provinsi Jawa Barat dan PDRB terendah adalah Provinsi Nusa Tenggara Timur. Rata-rata output produksi pada tahun 2017-2018 adalah 16.992,99, dengan output produksi industri mikro dan kecil tertinggi terjadi di Provinsi Jawa Barat pada tahun 2017 sebesar Rp122.335,2 M sedangkan output produksi terendah terjadi di Provinsi Sulawesi Barat pada tahun 2017 sebesar Rp1.129,637 M.

Tabel 2. Statistik Deskriptif Variabel Model Penelitian

\begin{tabular}{|l|c|c|c|c|c|c|}
\hline & PDRB & OUTPUT_PROD & UMl & PMTB & IMK & PD \\
\hline Mean & 74048.73 & 16992.99 & 35.11344 & 98841.8 & 131616.4 & 8.304091 \\
\hline Median & 14980.5 & 6234.694 & 5.9276 & 40197.24 & 71963 & 8.29 \\
\hline Maximum & 616442 & 122335.2 & 417.616 & 737730.3 & 1051144 & 11.05 \\
\hline Minimum & 800 & 1129.637 & 0.0326 & 7158.016 & 4514 & 6.27 \\
\hline Observations & 66 & 66 & 66 & 66 & 66 & 66 \\
\hline
\end{tabular}

Sumber: Diolah dengan Eviews 10

Sesuai dengan latar belakang, tujuan, dan penelitian-penelitian sebelumnya, penelitian ini dilakukan untuk menguji apakah Pembiayaan UMi memiliki daya dorong terhadap output industri pengolahan skala mikro dan kecil dan PDRB sektor industri pengolahan dengan menggunakan PMTB, jumlah industri mikro dan kecil (IMK) dan pendidikan sebagai variabel kontrol. Selain itu, penelitian ini juga bertujuan untuk mengetahui apakah terdapat hubungan tidak langsung antara Pembiayaan UMi dan PDRB sektor industri pengolahan dengan output industri pengolahan mikro dan kecil sebagai variabel mediasi.

Tabel 3. Hasil Regresi Pembiayaan Ultra Mikro (UMi) terhadap Pertumbuhan Ekonomi (PDRB)

\begin{tabular}{ccccc}
\hline \hline Variable & Coefficient & Std. Error & t-Statistic & Prob. \\
\hline \hline C & 7.252307 & 0.509319 & 14.23923 & 0.0000 \\
LOG(UMI) & 0.005276 & 0.007289 & 0.723792 & 0.4720 \\
PMTB & $3.95 \mathrm{E}-06$ & $7.45 \mathrm{E}-07$ & 5.303034 & 0.0000 \\
IMK & $6.71 \mathrm{E}-07$ & $2.12 \mathrm{E}-07$ & 3.159950 & 0.0025 \\
PD & 0.250157 & 0.058885 & 4.248242 & 0.0001 \\
\hline \hline
\end{tabular}

Sumber: Diolah dengan Eviews 10
Persamaan 1 menunjukkan hubungan langsung Pembiayaan UMi terhadap PDRB sektor industri pengolahan. Berdasarkan hasil regresi diketahui bahwa variabel LOG(UMi) memiliki nilai koefisien 0,005276 dengan probabilitas 0,4720. Hal tersebut menunjukkan bahwa LOG(UMI) tidak memiliki pengaruh signifikan terhadap LOG(PDRB) sehingga $\mathrm{H} 1$ ditolak.

Pembiayaan UMi secara spesifik merancang skema pencairan yang spesifik dan inklusif. Sebagai contoh, PT. Permodalan Nasional Madani menyalurkan Pembiayaan UMi dengan nama program Mekaar. Program ini menyasar wanita prasejahtera secara berkelompok dan mengharuskan adanya pertemuan rutin yang dilakukan kelompok tersebut. PT. Bahana Artha Ventura juga mendistribusikan Pembiayaan UMi melalui koperasi, salah satunya adalah Koperasi Mitra Dhuafa (KOMIDA) yang lebih banyak memberikan pinjaman kepada kaum perempuan. Beberapa alasan mengapa KOMIDA lebih berfokus pada debitur perempuan adalah karena perempuan dianggap lebih tekun dan teliti dalam pengembalian pinjaman, memiliki strategi yang lebih baik dalam menghadapi kemiskinan dan lebih berfokus pada keluarga dan keberhasilan anak-anaknya.

Dengan menggunakan LKBB sebagai lembaga penyalur Pembiayaan UMi, maka jangkauan Pembiayaan UMi terhadap industri mikro dan kecil menjadi semakin luas. Semakin dekatnya masyarakat dengan sumber permodalan maka ada kecenderungan peningkatan produktivitas usaha maupun industri mikro dan kecil. Skema penyaluran Pembiayaan UMi sebenarnya sudah merupakan strategi yang baik untuk memaksimalkan dampak Pembiayaan UMi terhadap perekonomian usaha mikro dan kecil sekaligus mendorong PDRB sektor industri pengolahan. Adapun penyaluran Pembiayaan UMi berdasarkan sektor ekonomi ditunjukkan pada Gambar 2 .

Gambar 2. Penyaluran Pembiayaan UMi Berdasarkan Sektor Ekonomi

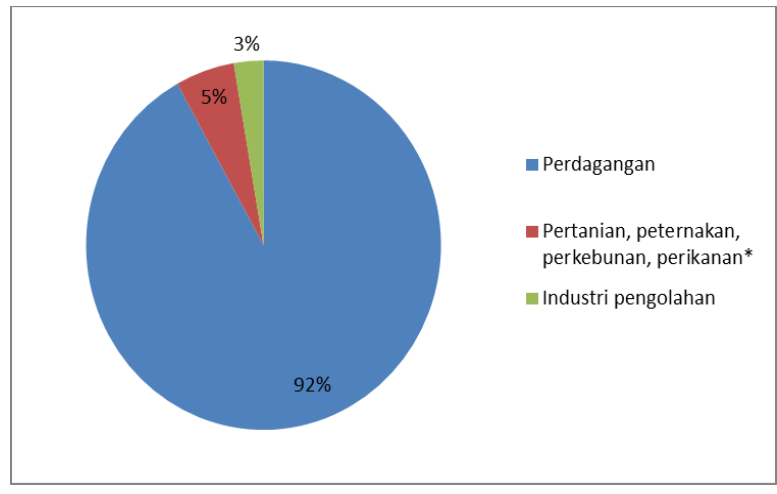

Sumber: Pusat Investasi Pemerintah, Sistem Informasi Kredit Pemerintah 
Rendahnya penyerapan Pembiayaan UMi di sektor industri pengolahan diduga sebagai penyebab tidak berpengaruhnya Pembiayaan UMi terhadap PDRB. Sama seperti KUR, Pembiayaan UMi lebih banyak diserap oleh sektor perdagangan. Sebagai kontributor PDRB tertinggi di Indonesia, pemerintah sebaiknya berfokus meningkatkan penyaluran Pembiayaan UMi kepada pengusaha industri mikro dan kecil. Selain itu, jumlah pembiayaan yang maksimal sebesar Rp 10 juta per debitur dengan waktu pinjaman maksimal 52 minggu ini diduga masih sangat kecil untuk dapat mendorong perekonomian regional. Hal ini berbeda dengan kredit perbankan lainnya seperti KUR yang jumlah pinjamannya bisa mencapai Rp 25 juta - Rp 500 juta dengan waktu pinjaman di atas 1 tahun.

Tabel 4. Hasil Regresi Pembiayaan Ultra Mikro (UMi) terhadap Pertumbuhan Produksi Industri Mikro dan Kecil (OUTPUT_PROD)

\begin{tabular}{crrrr}
\hline \hline Variable & Coefficient & Std. Error & t-Statistic & Prob. \\
\hline \hline C & 6.865465 & 0.775857 & 8.848876 & 0.0000 \\
LOG(UMI) & 0.075175 & 0.038660 & 1.944533 & $0.0564^{*}$ \\
PMTB & $1.77 \mathrm{E}-06$ & $7.49 \mathrm{E}-07$ & 2.364136 & 0.0213 \\
IMK & $3.22 \mathrm{E}-06$ & $4.58 \mathrm{E}-07$ & 7.040761 & 0.0000 \\
PD & 0.163290 & 0.093791 & 1.741002 & $0.0867^{*}$ \\
\hline \hline
\end{tabular}

Sumber: Diolah dengan Eviews 10

Catatan: * Derajat keyakinan 90 persen

Persamaan 2 menggambarkan hubungan langsung antara Pembiayaan UMi [LOG(UMi)] terhadap pertumbuhan produksi industri mikro dan kecil [LOG(OUTPUT_PROD)]. Hasil regresi pada Tabel 4 menunjukkan bahwa pada tingkat keyakinan 90 persen, LOG(UMi) memiliki pengaruh signifikan terhadap pertumbuhan produksi industri mikro kecil [LOG(OUTPUT_PROD)] sehingga H2 diterima. Jika diinterpretasikan, maka setiap kenaikan 1 persen Pembiayaan UMi akan mengakibatkan kenaikan pertumbuhan output industri mikro dan kecil sebesar 0,075175 persen.

Gambar 3. Pergerakan Pembiayaan UMi dan Output Produksi Industri Mikro dan Kecil Tahun 20162018

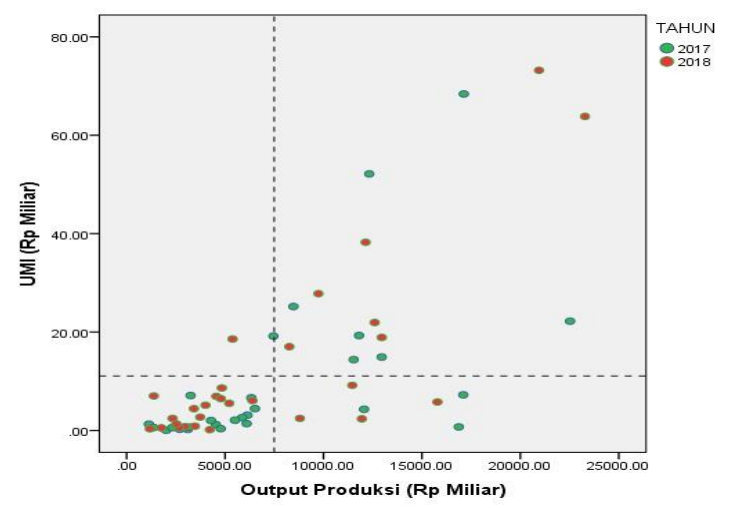

Sumber: Diolah dengan SPSS 40

Berdasarkan Gambar 3, dapat diketahui bahwa provinsi yang mendapat Pembiayaan UMi lebih sedikit, cenderung memiliki output produksi yang lebih sedikit pula. Begitu juga provinsi yang mendapat Pembiayaan UMi lebih banyak, cenderung memiliki output produksi yang lebih banyak pula. Pada tahun 2017 dan 2018, terdapat masing-masing 7 provinsi yang menerima Pembiayaan UMi dan memiliki output produksi di atas rata-rata (Gradien 1). Hal ini menunjukkan bahwa kenaikan Pembiayaan UMi berbanding lurus terhadap output produksi industri mikro dan kecil. Selain itu, dibutuhkan penelitian lebih lanjut terhadap 3 dan 4 provinsi pada tahun 2017 dan 2018 yang menerima Pembiayaan UMi lebih sedikit namun memiliki output produksi yang lebih banyak (Gradien 4). Diduga terdapat faktor-faktor lain selain Pembiayaan UMi yang mempengaruhi tingginya output produksi provinsi-provinsi tersebut.

Selain Pembiayaan UMi, unsur kapital pada penelitian ini juga ditunjukkan oleh Pembentukan Modal Tetap Bruto (PMTB) sebagai variabel kontrol. Tabel 3 menunjukkan bahwa PMTB, jumlah industri mikro dan kecil (IMK), dan pendidikan pelaku industri mikro dan kecil (Pd) secara langsung mempengaruhi pertumbuhan ekonomi, dalam hal ini PDRB. Hal ini sejalan dengan penelitian (Levine, 2005) dan (King \& Levine, 1993) yang menyebutkan pembiayaan mempunyai hubungan positif dengan pertumbuhan ekonomi. Penelitian lainnya juga menghubungkan pembiayaan UMKM, jumlah UMKM, pelatihan dan pendidikan, dengan perekonomian nasional (Kuzilwa, 2005), (Alimukhamedova, 2013), (Olukayode \& Somoye, 2013).

Pada hipotesis ketiga, penelitian ini menguji apakah terdapat pengaruh antara pertumbuhan produksi industri mikro dan kecil terhadap pertumbuhan ekonomi daerah yang diwakili oleh PDRB sektor industri pengolahan. Selain itu, persamaan ini juga menguji apakah output produksi industi mikro dan kecil [LOG(OUTPUT_PROD)] merupakan variabel mediasi dalam hubungan tidak langsung antara Pembiayaan UMi [LOG(UMi) dan PDRB sektor industri pengolahan [LOG(PDRB)]. Pengujian variabel mediasi dan hubungan tidak langsung ini dilakukan dengan melakukan analisis jalur.

Tabel 5. Hasil Regresi Pembiayaan Ultra Mikro (UMi) terhadap PDRB melalui Pertumbuhan Produksi Industri Mikro dan Kecil (OUTPUT_PROD)

\begin{tabular}{ccccc}
\hline \hline Variable & Coefficient & Std. Error & t-Statistic & Prob. \\
\hline \hline C & 6.815945 & 0.548724 & 12.42145 & 0.0000 \\
LOG(OUTPUT_PROD) & 0.039324 & 0.019501 & 2.016530 & 0.0482 \\
LOG(UMI) & 0.007769 & 0.007319 & 1.061497 & 0.2927 \\
PMTB & $4.11 \mathrm{E}-06$ & $7.43 \mathrm{E}-07$ & 5.528121 & 0.0000 \\
IMK & $6.07 \mathrm{E}-07$ & $2.12 \mathrm{E}-07$ & 2.858466 & 0.0058 \\
PD & 0.258898 & 0.058436 & 4.430456 & 0.0000 \\
\hline \hline
\end{tabular}

Sumber: Diolah dengan Eviews 10 
Berdasarkan Tabel 5 diketahui bahwa LOG(OUTPUT_PROD) memiliki nilai koefisien positif dan signifikan terhadap LOG(PDRB), yaitu sebesar 0,039324. Hal ini berarti pertumbuhan produksi industri mikro dan kecil berpengaruh signifikan terhadap PDRB sektor industri pengolahan sehingga H3 diterima. Jika diinterpretasikan, kenaikan 1 persen LOG(OUTPUT_PROD) akan mengakibatkan kenaikan LOG(PDRB) sebesar 0,039324 persen. Hal ini senada dengan pernyataan Tregenna (2011) bahwa industri pengolahan memiliki komponen engine of growth. Oleh sebab itu, dengan mendorong pertumbuhan produksi industri mikro dan kecil secara khusus dan sektor pengolahan secara umum, pemerintah dapat mendorong perekonomian rakyat sekaligus meningkatkan PDRB.

Hipotesis keempat (H4) penelitian ini bertujuan membuktikan adanya pengaruh tidak langsung Pembiayaan UMi terhadap pertumbuhan ekonomi daerah melalui pertumbuhan produksi industri mikro dan kecil. Pembuktian tersebut dilakukan dengan analisis jalur, yang mensyaratkan variabel independen LOG(UMi) harus memiliki pengaruh signifikan pada persamaan 1 dan 2 . Tabel 3 dan Tabel 5 menunjukkan bahwa LOG(UMi) tidak berpengaruh signifikan terhadap LOG(PDRB) sehingga tidak memenuhi kriteria variabel mediasi menurut Sekaran dan Bougie (2016). Oleh sebab itu, dapat disimpulkan bahwa pertumbuhan produksi industri mikro dan kecil [LOG(OUTPUT_PROD)] bukan merupakan variabel mediasi atas variabel independen [LOG(UMi)] dan variabel dependen [LOG(PDRB)]. Penelitian ini membuktikan tidak adanya hubungan tidak langsung antara Pembiayaan UMi [LOG(UMi)] terhadap pertumbuhan ekonomi regional [LOG(PDRB)] melalui pertumbuhan output produksi industri mikro dan kecil [LOG(OUTPUT_PROD)], sehingga H4 ditolak.

Gambar 4. Hubungan Pembiayaan Ultra Mikro (UMi) dan Pertumbuhan Produksi IMK terhadap PDRB Sektor Industri Pengolahan

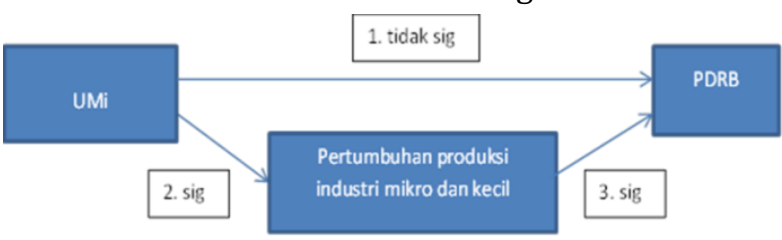

Sumber: Diolah oleh Penulis

Tabel 5 menggambarkan pengaruh Pembiayaan UMi, PMTB, jumlah industri mikro dan kecil serta tingkat pendidikan terhadap pertumbuhan produksi dan PDRB. Dapat diketahui bahwa seluruh Pembiayaan UMi berpengaruh signifikat terhadap output produksi industri mikro dan kecil, namun tidak berpengaruh signifikan terhadap PDRB. Selain itu, dapat diketahui bahwa seluruh variabel kontrol memiliki pengaruh signifikan terhadap output produksi industri mikro dan kecil dan PDRB.

Tabel 6. Signifikansi Variabel Penelitian

\begin{tabular}{|l|c|c|c|}
\hline \multicolumn{1}{|c|}{ Variabel } & LOG(OUTPUT_PROD) & LOG(PDRB) & LOG(PDRB) \\
\hline LOG(OUTPUT_PROD) & $\cdot$ & $\cdot$ & Signifikan \\
\hline LOG(UMI) & Signifikan* & Signifikan & Tidak signifikan \\
\hline PMTB & Signifikan & Signifikan & Signifikan \\
\hline IMK & Signifikan & Signifikan & Signifikan \\
\hline PD & Signifikan* & Signifikan & Signifikan \\
\hline
\end{tabular}

Sumber: Diolah dengan Eviews 10

Catatan: * Derajat keyakinan 90 persen

\section{KESIMPULAN DAN SARAN}

Penelitian ini diadakan untuk menilai apakah kebijakan pemerintah Indonesia melalui intervensi pembiayaan kepada usaha ultra mikro yang dilakukan pada tahun 2017 hingga sekarang memiliki daya dorong terhadap produksi industri mikro dan kecil sekaligus meningkatkan pertumbuhan ekonomi regional. Dari hasil analisis terhadap hipotesis diperoleh kesimpulan sebagai berikut.

a. Pembiayaan UMi tidak memiliki pengaruh signifikan terhadap pertumbuhan ekonomi yang diwakili oleh PDRB sektor industri pengolahan ( $\mathrm{H}_{1}$ ditolak).

b. Pembiayaan UMi memiliki pengaruh signifikan terhadap pertumbuhan output produksi industri mikro dan kecil ( $\mathrm{H}_{2}$ diterima).

c. Pertumbuhan output produksi industri mikro dan kecil berpengaruh signifikan terhadap pertumbuhan ekonomi daerah (PDRB) $\left(\mathrm{H}_{3}\right.$ diterima).

d. Output produksi industri mikro dan kecil bukan merupakan variabel mediasi antara Pembiayaan UMi dan PDRB sektor industri pengolahan ( $\mathrm{H}_{4}$ ditolak).

Melalui penelitian ini, disimpulkan bahwa pada derajat keyakinan 90 persen, Pembiayaan UMi berpengaruh positif dan signifikan terhadap pertumbuhan produksi industri mikro dan kecil dengan koefisien sebesar 0,075175. Hal ini menunjukkan bahwa program kredit non perbankan ini dapat digunakan oleh pemerintah untuk mendorong pertumbuhan produksi industri mikro dan kecil. Meskipun begitu, Pembiayaan UMi belum mampu memberi pengaruh signifikan terhadap PDRB. Hal ini kemungkinan terjadi karena rendahnya nilai pinjaman per penerima dan rendahnya penyaluran Pembiayaan UMi yang diterima oleh sektor industri pengolahan. Seperti yang ditunjukkan pada Gambar 2, sektor industri pengolahan hanya menerima 3 persen dari total realisasi Pembiayaan UMi, sedangkan sektor perdagangan menerima hingga 92 persen dari total realisasi. Tingginya penyerapan Pembiayaan UMi oleh sektor perdagangan juga mengindikasikan 
bahwa usaha ultra mikro di Indonesia masih bersifat ektraktif dan tidak kreatif.

Adapun pertumbuhan produksi industri mikro kecil juga terbukti berpengaruh positif dan signifikan terhadap pertumbuhan ekonomi (PDRB). Tregenna (2011) menyebutkan bahwa industri pengolahan memiliki komponen engine of growth. Pemerintah dapat mendongkrak PDRB dengan cara mendorong pertumbuhan produksi industri mikro kecil secara khusus dan sektor industri pengolahan secara umum. Lebih lanjut lagi Tregenna menyebutkan bahwa salah satu usaha yang dapat dilakukan negara berkembang untuk meningkatkan level kontribusi industri pengolahan terhadap PDB adalah dengan intervensi pemerintah. Sebagai bentuk intervensi pemerintah dan variabel independen dalam penelitian ini, Pembiayaan UMi terbukti dapat mendorong produktifitas industri mikro kecil dan PDRB sektor industri pengolahan. Oleh sebab itu, sebagai fund coordinator, PIP disarankan dapat secara aktif meningkatkan pembiayaan non perbankan ini dan melakukan kerjasama dengan pihak pemda, swasta dan asing agar program ini bisa terus berkesinambungan.

\section{IMPLIKASI DAN KETERBATASAN}

Pembiayaan UMi merupakan bentuk intervensi pemerintah terhadap permasalahan masih sedikitnya usaha mikro dan kecil yang dapat mengakses KUR. Dengan adanya program ini, pemerintah berharap seluruh pengusaha mikro dan kecil memiliki kesempatan yang sama dan mudah terhadap modal. Hal ini sesuai dengan yang diungkapkan oleh Lin (1994) bahwa pengeluaran pemerintah dapat mendorong terciptanya keseimbangan sosial dan produktifitas tenaga kerja.

Pembiayaan UMi dalam penelitian ini memiliki pengaruh yang signifikan terhadap produksi industri mikro dan kecil namun tidak berpengaruh terhadap PDRB sedangkan produksi berpengaruh signifikan terhadap PDRB. Hal ini berarti ada faktorfaktor selain Pembiayaan UMi yang merupakan komponen variabel produksi, yang mendorong PDRB sektor industri pengolahan. Dibutuhkan penelitian lebih lanjut untuk mengetahui faktorfaktor tersebut sehingga pemerintah dapat berfokus pada optimalisasi faktor-faktor tersebut.

Objek penelitian ini hanya menggunakan data 33 provinsi di Indonesia periode 2017-2018 karena Pembiayaan UMi baru disalurkan pertama kali pada tahun 2017 dan belum mencakup provinsi Kalimantan Utara. Periode penelitian yang lebih panjang dan objek penelitian yang lebih banyak memungkinkan hasil penelitian yang berbeda dan lebih menggambarkan kondisi yang sebenarnya.

\section{DAFTAR PUSTAKA}

Amalia, F. (2014). Analisis Fungsi Produksi CobbDouglas Pada Kegiatan Sektor Usaha Mikro Di Lingkungan Uin Syarif Hidayatullah Jakarta. Signifikan: Jurnal Ilmu Ekonomi, 3(1), 45-62. https://doi.org/10.15408/sigf.v3i1.2056

Antonio, M. S. 2001. Bank Syariah Dari Teori Ke Praktik. Jakarta: Gema Insani Press.

Asmara, C. G. (2020, April 7). Sri Mulyani: UMKMTKI Boleh Tunda Bayar Pokok \& Bunga KUR. CNBC Indonesia. Retrieved from https://www.cnbcindonesia.com/market/20 200407132252-17-150307/sri-mulyaniumkm-tki-boleh-tunda-bayar-pokok-bungakur

Assefa Admassie, \& Matambalya, F. A. S. T. (2002). Technical Efficiency of Small-and MediumScale Enterprises: Evidence from a Survey of Enterprises in Tanzania. Eastern Africa Social Science Research Review, 18(2), 1-29. https://doi.org/10.1353/eas.2002.0007

Batool, S. A., \& Zulfiqar, S. (2013). Analyzing the Input Output Relationship of Small and Medium Enterprises in Pakistan: An Econometric Approach. International Journal of Business and Economic Development, 1(1), 66-73. Retrieved from https://mpra.ub.unimuenchen.de/50069/

Cobb, C. W., \& Douglas, P. H. (1928). A Theory of Production. American Economic Association. America Economic Association. https://doi.org/10.1515/humr.1998.11.2.11

Gujarati, D. (2003). Basic Econometric (4th ed.). New York: McGraw-Hill.

Gupta, V., Saini, J. S., \& Chaddha, S. (2018). MSME Financing: Growth and Challenges. International Journal for Research in Engineering Application \& Management, 04(07), 716-727. https://doi.org/10.18231/24549150.2018.1036

Haller, A. (2012). Concepts of Economic Growth and Development. Challenges of Crisis and of Knowledge, 15(1), 66-71.

Hofmann, J., \& Werkheiser, C. (2017). Efficiency of Fixed and Random Effects Estimators: A Monte Carlo Analysis. Journal of Chemical Information and Modeling, 8(9), 1-58. https://doi.org/10.1017/CB0978110741532 4.004

IFC. (2011). SME Finance Policy Guide. Washington.

Indonesia, R. Undang-Undang Nomor 20 Tahun 2008 tentang Usaha Mikro, Kecil, dan Menengah, Pub. L. No. 20, 1 (2008). Indonesia. Retrieved from https://m.hukumonline.com/pusatdata/detai l/28029/undangundang-nomor-20-tahun2008

Lin, S. A. Y. (1994). Government spending and economic growth. Applied Economics, 26(1), 
83-94.

https://doi.org/10.1080/000368494000000

64

Menteri Keuangan. Peraturan Menteri Keuangan Nomor 95/PMK/05/2018 tentang

Pembiayaan Ultra Mikro, Pub. L. No. 95 (2018). Indonesia. Retrieved from www.jdih.kemenkeu.go.id

Menteri Koordinator Bidang Perekonomian, R. I. Pedoman Pelaksanaan Kedit Usaha Rakyat, Pub. L. No. 11, Permenko 11 Tahun 2017 (2017). Indonesia: Menteri koordinator Bidang Perekonomian. Retrieved from

http://kur.ekon.go.id/upload/doc/permenko-11tahun-2017-publish.pdf

Mulyadi. 2006. Akuntansi Manajemen (3rd ed.). Jakarta: Salemba Empat.

Ooi, E., Atkinson, A., \& Messy, F.-A. (2017). Financial Education for Micro, Small and Medium-Sized Enterprises in Asia. Jakarta. Retrieved from www.financial-education.org

Panigrahi, A. K. (2012). Risk Management in Micro, Small and Medium Enterprises (MSMEs) in India: A Critical Appraisal. Asia Pacific Journal of Marketing \& Management Review, 1(4).

Pemerintah, P. I. (2019). Pembiayaan Ultra Mikro (UMi). Retrieved April 23, 2020, from https://www.kemenkeu.go.id/umi

Rewilak, J. (2017). The role of financial development in poverty reduction. Review of Development Finance, $\quad 7(2), \quad 169-176$. https://doi.org/10.1016/j.rdf.2017.10.001

Sekaran, U., \& Bougie, R. (2016). Research Methods For Business. In Encyclopedia of Quality of Life and Well-Being Research (Seventh). https://doi.org/10.1007/978-94-007-07535_102084

Tandeilin, E. 2010. Portofolio dan Investasi : Teori dan Aplikasi (1st ed.). Yogyakarta: Kanisius.

Tregenna, F. (2011). WIDER Working Paper No. 2011/57 Manufacturing Productivity, Deindustrialization, and Reindustrialization.

Vandenberg, P. (2009). Micro, Small and Mediumsized Enterprises and the Global Economic Crisis Impacts and Policy Responses (First). Geneva: International Labour Office. Retrieved from http://www.ilo.org/publns

Veithzal, Rivai, \& Ariviyan Arivin (2010). Islamic Banking Sebuah Teori, Konsep, dan Aplikasi, 681. Jakarta: PT. Bumi Aksara .

Wardhono, A., Modjo, M. I., \& Utami, E. W. (2019). The Role of Credit Guarantee Schemes For Financing MSMEs: Evidence From Rural And Urban Areas In Indonesia. Tokyo. 